\title{
UJI AKTIVITAS ANTIOKSIDAN VARIAN JUS DELIMA (Punicagranatum L.) DENGAN METODE FRAP
}

\section{A. Muflihunna, Sukmawati Syarif, Dian Rahmawati}

Fakultas Farmasi Universitas Muslim Indonesia

Email : amchund124@gmail.com

\begin{abstract}
A research test the antioxidant activity of pomegranate juice (Punicagranatum L.) with the FRAP method to measure and determine antioxidant activity. Pomegranate juice was analyzed qualitatively by using the metod FRAP with FRAP reagent. Quantitatively mix with the sample solution was analyzed by FRAP method UV-VIS Spectrophotometer at a wavelength $596 \mathrm{~nm}$. By using trolox as a reference standard. From the research result that sample $A$ and sample $B$ sample $C$ has antioxidant activity with an total value of antioxidant activity, sample $A=6.1243 \mu \mathrm{mol}$ $T R / g$ sample, sample $B=6.0913 \mu \mathrm{molTR} / g$ sample and sample $C=2.9651$ $\mu \mathrm{molTR} / \mathrm{g}$ sample.
\end{abstract}

Key words : Pomegranate juice, antioxidant activity, FRAP, Trolox Uv-Vis Spectrophotometer.

\section{PENDAHULUAN}

Jus adalah minuman sari buah atau sayuran yang diperoleh dari proses pemerasan sehingga akan diperoleh cairan sari buah atau sayuran. Mengkonsumsi jus buah atau sayuran dianjurkan oleh National Academy of Sciences karena banyak mengandung senyawa kimia yang dapat menurunkan resiko penyakit degeneratif. Jus buah dan sayuran kaya akanantioksidan (Ide, 2010).

Antioksidan adalah pelindung sel tubuh agar tidak rusak oleh radikal bebas. Radikal bebas adalah suatu atom yang kehilangan pasangan sehingga akan merusak sel-sel sehat. Antioksidan menstabilkan radikal bebas dengan melengkapi kekurangan elektron yang dimiliki radikal bebas, dan menghambat terjadinya reaksi berantai dari pembentukan radikal bebas. Radikal bebas ini dapat terbentuk dalam tubuh atau dari luar tubuh. Sel-sel yang rusak oleh radikal bebasdapat berubah menjadi sel kanker atau menyebabkan penyakit degeneratif lain (Rozaline, 2006).

Salah satu buah yang kaya akan kandungan antioksidan adalah buah delima (Punica granatum L.). 
Pemanfaatan buah delima untuk keperluan kesehatan telah dilakukan sejak lama, karena memiliki aktivitas antioksidan yang tinggi. Hal ini dibuktikan berdasarakn publikasi jurnal tentang aktivitas antioksidan buah delima antara lain yaitu, pameran antivirus, antioksidan, antidiabetik, antidiare, anti kanker dan aktivitas antiproliferatif (Dkhil et al, 2013), ekstrak buah delima selektif menghambat pertumbuhan sel-sel kanker payudara, prostat dan usus (Adhami et al, 2009), dan efek aterosklerotik yang telah dikonfirmasi (Weerakkody et al, 2012).

Tanaman delima (Punica granatum L.) pada kulit buah mengandung alkaloid pelletierine, granatin, betulic acid, ursolic acid, isoquercitrin, resin, triterpenoid, kalsium oksalat dan pati. Kulit akar dan kulit kayu mengandung sekitar 20\% elligatanin, dan $0,5 \%$ - $1 \%$ senyawa alkaloid. Daun mengandung alkaloid, tannin, kalsium oksalat, lemak, sulfur, peroksidase. Jus buah mengandung asam sitrat, asam galat, glukosa, fruktosa, maltose, vitamin ( $A$ dan $C$ ), mineral dan tannin (Utami, 2008).

Seiring berjalannya waktu penelitian tentang buah delima (Punica granatum L.) telah berkembang dan memberikan hasil yang baik tentang efek farmakologinya. Hal inilah yang mendasari perlunya dilakukan penelitian tentang uji aktivitas antioksidan jus delima (Punica granatum L.) dengan metode FRAP.

\section{METODE PENELITIAN}

\section{Alat dan Bahan}

Alat yang digunakan yaitu, batang pengaduk,gelas kimia (Pirex), kuvet, labu Erlenmeyer (Pirex), labu ukur (Pirex), mikropipet (Dragonleb), setrifuge (OneMed 0508-1), spektrofotometer UV-Visible(Apel $P D$ 303 UV), tabung reaksi (Pirex), tabung sentrifuge (Pirex), timbangan analitik(Acis $A D-600 H)$.

Bahan yang digunakan adalah aquades, asam trikloroasetat (TCA) $10 \%$, buffer asetat $\mathrm{pH} 3,6$; etanol p.a 96\%, jus Delima (Punica granatum L), $\mathrm{HCl}, \mathrm{TPTZ}, \mathrm{FeCl}_{3}$.

\section{Prosedur Kerja}

\section{Penyiapan alat dan bahan}

Alat dan bahan disiapkan sesuai dengan kebutuhan penelitian yang akan dilaksanakan.

Pengambilan dan pengolahan sampel

Pengambilan sampeljus delima (Punica granatum L.) dilakukan di supermarket dikotaMakassar,dengan varian produk jus delima yang berbeda merek. 
Pengolahan sampel jus delima (Punica granatum L.) dipipet jus delima kemudian di sentrifuge dan diambil supernatannya.

Pembuatan larutan dan penentuan antioksidan total (Merujuk pada Selawa dkk, 2013 dengan beberapa modifikasi)

Pembuatan Larutan Pereaksi Larutan Buffer Asetat pH 3,6

Ditimbang 0,775 gram natrium asetat. Dimasukan dalam labu ukur $250 \mathrm{~mL}$ dan dilarutkan dengan $4 \mathrm{~mL}$ asam asetat pekat. Diukur $\mathrm{pH}$ dapar. Kemudian dicukupkan volumenya sampai batas tanda dengan aquadest.

\section{Larutan $\mathrm{HCl} 40 \mathrm{mmol} / \mathrm{L}$}

Dipipet $\mathrm{HCl}$ pekat sebanyak 0,33 $\mathrm{mL}$ kemudian dimasukan kedalam labu ukur $100 \mathrm{~mL}$. Dicukupkan volumenya sampai batas tanda dengan aquadest.

\section{Larutan TPTZ $10 \mathrm{mmol} / \mathrm{L}$}

Ditimbang sebanyak $25 \mathrm{mg}$ TPTZ kemudiandimasukan kedalam labu ukur dan dilarutkan dengan $\mathrm{HCl}$ pekat $40 \mathrm{mmol} / \mathrm{L}$ sebanyak $8 \mathrm{~mL}$.

\section{Larutan asam trikloroasetat $\mathbf{1 0 \%}$}

Ditimbang sebanyak 10 gramCCl $3 . \mathrm{CO}_{2} \mathrm{Hdilarutkan}$ dengan aquadest dalam labu ukur hingga batas tanda $100 \mathrm{~mL}$.

Larutan $\mathrm{FeCl}_{3} 20 \mathrm{mmol} / \mathrm{L}$

Ditimbang $\mathrm{FeCl}_{3}$ sebanyak 54 mg, kemudian dimasukan kedalam labu ukur $10 \mathrm{~mL}$ dan dilarutkan sampai batas tanda dengan aquadest.

\section{Reagen FRAP}

Reagen FRAP dibuat dengan cara mencampurkan $25 \mathrm{~mL}$ dapar asetat, 2,5 mL TPTZ, 2,5 mL $\mathrm{FeCl}_{3}$ kedalam labu ukur $100 \mathrm{~mL}$ dan dicukupkan volumenya dengan aquadest sampai batas tanda.

\section{Larutan Standar Trolox}

Larutan stok 600 $\mu$ Mdibuat dengan melarutkan $15 \mathrm{mg}$ trolox dengan etanoll p.a. Lalu di encerkan hingga batas labu ukur $100 \mathrm{~mL}$.

\section{Uji aktivitas antioksidan dengan metode FRAP}

\section{Penentuan Absorbansi Trolox}

Dari larutan stok 600 $\mathrm{MM}$ diambil masing-masing sebanyak 0,$83 ; 1,6$; 2,5; 3,3; 4,1; $5 \mathrm{~mL}$ dan ditempatkan pada labu ukur berbeda dan diencerkan dengan etanol hingga 5 $\mathrm{mL}$ dan dihomogenkan. Konsentrasi larutan standar trolox yang terbentuk berturut-turut $100 \mu \mathrm{M}, 200 \mu \mathrm{M}, 300 \mu \mathrm{M}$, $400 \mu \mathrm{M}, 500 \mu \mathrm{M}, 600 \mu \mathrm{M}$. Kemudian di pipet $1 \mathrm{ml}$ kedalam tabung reaksi masing-masing dari konstrasi larutan trolox, tambahkan $3 \mathrm{~mL}$ reagen FRAP dan di inkubasi pada suhu $37^{\circ} \mathrm{C}$ selama 30 menit, lalu diukur absorbansinya pada panjang gelombang $596 \mathrm{~nm}$ dengan spektrofotometer UV-Vis. 
Penentuan Absorbansi Sampel

\section{Sampel A}

$5 \mathrm{~mL}$ jus delima masukan dalam tabung setrifuge dan ditambahkan $1 \mathrm{~mL}$ TCA $10 \%$ lalu disentrifuge selama 10 menit dengan kecepatan 3000 rpm, diambil supernatan sebanyak $1 \mathrm{~mL}$. Selanjutnya untuk sampel A dibuat variasi pengenceran 1:5, 1:10, 1:14, 1:19 $\mathrm{mL}$ etanol untuk mendapatkan nilai absorbansi yang memenuhi nilai range dari baku pembanding, kemudian masing-masing dipipet $1 \mathrm{~mL}$ dan ditambahkan reagen FRAP $3 \mathrm{~mL}$ masing-masing sampel dibuat 3 replikasi. Di inkubasi pada suhu $37^{\circ} \mathrm{C}$ selama 30 menit, lalu diukur absorbansinya pada panjang gelombang $596 \mathrm{~nm}$ dengan spektrofotometer UV-Vis.

\section{Sampel B}

$5 \mathrm{~mL}$ jus delima masukan dalam tabung setrifuge dan ditambahkan $1 \mathrm{~mL}$ TCA $10 \%$ lalu disentrifuge selama 10 menit dengan kecepatan 3000 rpm, diambil supernatan sebanyak $1 \mathrm{~mL}$. Selanjutnya untuk sampel B dibuat variasi pengenceran 1:5, 1:10, 1:14, $1: 19 \mathrm{~mL}$ etanol untuk mendapatkan nilai absorbansi yang memenuhi nilai range dari baku pembanding, kemudian masing-masing dipipet $1 \mathrm{~mL}$ dan ditambahkan reagen FRAP $3 \mathrm{~mL}$ masing-masing sampel dibuat 3 replikasi. Di inkubasi pada suhu $37^{\circ} \mathrm{C}$ selama 30 menit, lalu diukur absorbansinya pada panjang gelombang $596 \mathrm{~nm}$ dengan spektrofotometer UV-Vis.

\section{Sampel C}

$5 \mathrm{~mL}$ jus delima masukan dalam tabung setrifuge dan ditambahkan $1 \mathrm{~mL}$ TCA $10 \%$ lalu disentrifuge selama 10 menit dengan kecepatan 3000 rpm, diambil supernatan sebanyak $1 \mathrm{~mL}$ dan diencerakn dengan $5 \mathrm{~mL}$ etanol.Kemudian dipipet $1 \mathrm{~mL}$ dan ditambahka reagen FRAP $3 \mathrm{~mL}$, sampel dibuat 3 replikasi dan di inkubasi pada suhu $37^{\circ} \mathrm{C}$ selama 30 menit, lalu diukur absorbansinya pada panjang gelombang $596 \mathrm{~nm}$ dengan spektrofotometer UV-Vis. 
HASIL PENELITIAN

Tabel 1. Hasil Pengukuran Absorbansi dan Nilai Aktivitas AntioksidanJus Delima (Punica granatum L.) dengan Metode FRAP

\begin{tabular}{ccccc}
\hline Sampel & Replikasi & Absorbansi (Y) & $\begin{array}{c}\text { Aktivitas Antioksidan } \\
(\boldsymbol{\mu} \text { M TR/ g sampel) }\end{array}$ & $\begin{array}{c}\text { Rata-Rata Aktivitas } \\
\text { Antioksidan } \\
(\boldsymbol{\mu M} \text { TR / g sampel) }\end{array}$ \\
\hline \multirow{2}{*}{ Sampel A } & I & 0,262 & 6,7561 & 6,1243 \\
\hline \multirow{2}{*}{ Sampel B } & II & 0,189 & 5,4926 & 6,0913 \\
\hline \multirow{2}{*}{ Sampel C } & II & 0,214 & 5,8644 & 2,9651 \\
& I II & 0,240 & 6,3182 & \\
\hline
\end{tabular}

\section{PEMBAHASAN}

Delima merupakan tumbuhan yang kaya akan kandungan antioksidan. Manfaat dari buah delima dalam memerangi radikal bebas yang dapat menyebabkan penyakit degeneratif telah banyak diteliti oleh para ilmuan. Kandungan kimia dari buah delima yaitu flavonoid, palifenol dan katekin serta vitamin $A$ dan vitamin C. Dimana senyawa-senyawa ini merupakan antioksidan kuat yang berguna mencegah berkembanganya radikal bebas dalam tubuh dan memperbaiki sel-sel tubuh yang rusak. Maka dari itu dilakukan uji aktivitas antioksidan dari varian jus delima (Punica granatum L.) dengan menggunakan metode FRAP (Ferric Reducing Antioxidant Power).

Menurut Benzie dan
Strain(1996), metode
merupakan metode untuk mengukur
aktivitas antioksidan yang didasarkan

pada kempuan dalam mereduksi ion ferri $\left(\mathrm{Fe}^{3+}\right)$ menjadi ion ferro $\left(\mathrm{Fe}^{2+}\right)$ pada $\mathrm{pH}$ rendah. Dimana akan membentuk kompleks warna biru yang menandakan adanya aktivitas antioksidan pada sampel.

Penentuan nilai aktivitas antioksidan dilakukan dengan mencampurkan reagen FRAP dengan sampel jus delima. Dimana dalam reagen FRAP terdapat campuran TPTZ, $\mathrm{FeCl}_{3}$ dan buffer asetat. Penambahan $\mathrm{FeCl}_{3}$ dalam reagen yaitu untuk membentuk senyawa kompleks $\mathrm{Fe}^{3+}$ dan memperlambat reaksi reduksi $\mathrm{Fe}^{3+}$ menjadi $\mathrm{Fe}^{2+}$ yang terjadi sangat cepat oleh pengaruh cahaya. Sedangkan penambahan buffer asetat adalah karena buffer ini memiliki $\mathrm{pH}$ efektif dari 3,6 - 5,6 (Gholib, 2007). Dimana telah diketahui bahwa reaksi reduksi $\mathrm{Fe}^{3+}-$ TPTZ menjadi Fe ${ }^{2+}-$ TPTZ terjadi pada suasana asam atau $\mathrm{pH}$ rendah sehingga digunakan buffer 
asetat dengna pH efektif terendah 3,6.

Ou etal(2002) dalam Istiningrum (2013), mengatakan senyawa $\mathrm{Fe}^{3+}$ TPTZ mewakili senyawa oksidator yang mungkin terdapat dalam tubuh dan dapat merusak sel-sel tubuh, sedangkan sampel mengandung antioksidan yang dapat mereduksi senyawa $\mathrm{Fe}^{3+}-\mathrm{TPTZ}$ menjadi $\mathrm{Fe}^{2+}$ TPTZ sehingga senyawa $\mathrm{Fe}^{3+}-\mathrm{TPTZ}$ tidak akan melakukan reaksi yang dapat merusak sel-sel tubuh.

Larutan standar yang digunakan pada pada uji aktivitas antioksidan ini adalah trolox. Trolox biasa digunakan sebagai standar positif dalam uji antioksidan. Trolox merupakan analog dari vitamin $\mathrm{E}$ yang merupakan antioksidan kuat. Menurut Devies et al
(1988), perbedaan dari trolox dan vitamin $E$ yaitu pada pergantian rantai samping hidrokarbon dengan gugus $\mathrm{COOH}$.

Penentuan kandungan total aktivitas antioksidan jus delima dilakukan pada panjang gelombang maksimum $596 \mathrm{~nm}$ pada spektrofotometer Uv-vis sehingga didapatkan nilai berupa absorbansi. Nilai absorbansi dari pengukuran sampel A, sampel B dan sampel C dimasukan kedalam persaman linear $y$ $=\mathrm{a}+\mathrm{bx}$. Dimana telah diperoleh nilai $\mathrm{a}$ dan bx dari kurva baku larutan standar trolox yaitu, $y=0.001 x-0.122$. Nilai aktivitas antioksidan dihitung dengan rumus :

$$
\begin{array}{r}
\text { Aktivitas antioksidan }(\mu \mathrm{MTR} / \mathrm{gsampel}) \\
=\frac{V \operatorname{sampel}(\mathrm{ml}) \times[\text { sampel }] \times f p \times 10^{-3}}{\operatorname{Bobotsampel}(g)}
\end{array}
$$

Sampel A untuk replikasi pertama, absorbansi sampel adalah 0,262 dengan aktivitas antioksidan

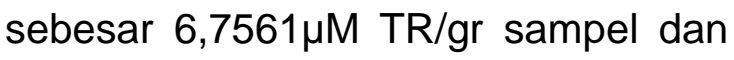
replikasi kedua, absorbansi sampel adalah 0,189 dengan aktivitas antioksidan sebesar 5,4926 $\mu \mathrm{M} \mathrm{TR} / \mathrm{gr}$ sampel. Dengan nilai aktivitas antioksidan rata-rata dari sampel $A$

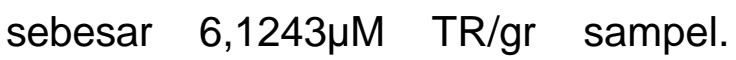
Sampel B untuk replikasi pertama, absorbansi sampel adalah 0,214 dengan aktivitas antioksidan sebesar 5,8644 $\mu \mathrm{M} \mathrm{TR} / \mathrm{gr}$ sampel dan replikasi kedua, absorbansi sampel adalah 0,240 dengan aktivitas antioksidan sebesar 6,3182 $\mu \mathrm{M} \mathrm{TR} / \mathrm{gr}$ sampel. Dengan nilai aktivitas antioksidan ratarata dari sampel B sebesar 6,0913 $\mu \mathrm{M}$ TR/gr sampel. Sampel C untuk replikasi pertama, absorbansi sampel adalah 0,560 dengan aktivitas 
antioksidan sebesar $3,2414 \mu \mathrm{M} \mathrm{TR} / \mathrm{gr}$ sampel dan replikasi kedua, absorbansi sampel adalah 0,592 dengan aktivitas antioksidan sebesar 3,3755 $\mu \mathrm{M}$ TR/gr sampel, dan replikasi ketiga, absorbansi sampel adalah 0,578 dengan aktivitas antioksidan sebesar 2,2786 $\mu \mathrm{M}$ TR/gr sampel. Dengan nilai aktivitas antioksidan ratarata dari sampel $\mathrm{C}$ sebesar $2,9651 \mu \mathrm{M}$ TR/gr sampel.

Cukup tingginya nilai aktivitas antioksidan yang dihasilkan menunjukan bahwa dalam sampel jus delima kandungan senyawa kimia masih terjaga dengan baik setelah melewati proses pengolahan dan pemasaran. Kandungan senyawa kimia dalam jus delima terbukti bertanggung jawab sebagai antioksidan yang baik.

Perbedaan nilai aktivitas antioksidan pada setiap sampel, dipengaruhi oleh jumlah konsentrasi jus delima dalam sampel yang berbedabeda dan juga dari sumber produk serta bahan baku yang digunakan yaitu, sampel A dan B merupakan produk minuman impor dengan komposisi minuman mengandung jus buah delima asli sedangakan untuk sampel $\mathrm{C}$ merupakan produk minuman lokal dengan komposisi minuman mengandung konsetrat buah delima.

\section{KESIMPULAN}

Dari hasil penelitian dapat disimpulkan bahwa:

1. Semua sampel ujimemiliki aktivitas sebagai antioksidan.

2. Total aktivitas antioksidan tertinggi berturut-turut yaitu, sampel $A=$

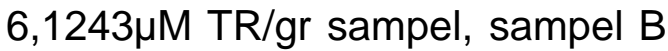
$=6,0913 \mu \mathrm{M}$ TR/gr sampel dan sampel $C=2,9651 \mu \mathrm{M} \quad \mathrm{TR} / \mathrm{gr}$ sampel.

\section{DAFTAR PUSTAKA}

Adhamin, M., Khan,N., Mukthar, H. 2009. Cencer Chemoprevention by Pomegranate : Laboratory and Clinical Evidence. Nutr Cencer. 61(6). 811-815

Apak R., Kubilay G., Birsen D., Mustafa O. , Saliha E.C. , Burcu B. , K. Işı| B.and Dilek O. 2007. Comparative evaluation of various total antioxidant capacity assayapplied to phenolic compounds with the CUPRAC assay. Molecules 12:1496-1547.

Beedetti, M, G., Foster, A, L., Vantipalli, M, C. 2007. Trolox Enhances the Anti-Lyprphoma Effects Arsenic Trioxide, While Protecting Against Liver Toxicity. Leukimia. 21: 21172127.

Benzie IFF, Strain JJ. 1996. The ferricreducing ability of plasma (FRAP) as ameasurement of 'antioxidant power' : the FRAP assay. Analytical Biochemistry 239:70-76. 
Corwin, J. Elizabeth. 2008. Buku Saku Patofisiologi, ed. 3. ECG : Jakarta.

Cos, P., Hemans, N., Calomme, M. 2003. Comparative Study of Eight well-known Polyphenolic antioxidant. JPharm Pharmacol. 55 1291-1297.

Davies, J., Forni, G., Willson, L. 1988. Vitamin E Analogue Trolox C. E.S.R and Pulse-radiolysis Studies of Free-radical Reactions. Biochemistry J. 225. 513-522

Diaz, M,. Moscat, J., Maria, T. 2007. p62 at the Crossroads of Autophagy, Apoptosis and Cancer. Elsevier Inc. 137 (1001-1004).

Dkhil, A., Al-Quraishy, S., Abdel, M. 2013. Effect of Pomegranate (Punica granatum L.) Juice and Methanolic Peel Extract On Testis of Male Rats. Pakistan J Zool. 45(5). 13431349

Evira, D. 2013. The Miracel of Friuts. AgroMedia Pustaka : Jakarta

Gholib, G., Rohman, A. 2007. Kima Farmasi: Analisis. Pustaka Pelajar. Yogyakarta

Harmanto, N. 2007. Jus Herbal. Alex Media Komputindo : Jakarta

Ide, P. 2008. Gaya Hidup Penghambat ALZHEIMER. Alex Media Computindo: Jakarta.

Ide, P. 2010. Health Secret of Pepin. Alex Media Computindo: Jakarta.
Istiningrum, R. 2013. Analysis of Antioxidant Capacity on Ingredients og Lotek Menu by Ferric Reducing. Eksakta. 13(12). 40-48.

Khopkar, S.M. 2008. Konsep Dasar Kimia Analitik. UI-Press: Jakarta.

Rozaline, H. 2006. Terapi Jus Buah dan Sayur. Niaga Swadaya: Jakarta

Rukmana, R. 2003. Delima. Kanisuis: Yogyakarta.

Selawa W., Runtuwene M., Citraningtyas G. 2007. Kandungan Flavonoid dan Kapasitas Antioksidan Total Ekstrak Etanol Daun Binahong (Andredera cordifolia (Ten.)Steenis). Pharmacon Jurnal Ilmiah Farmasi.Vol 2(1):2302 - 2493

Simiati, M. I. 2012. Uji Aktivitas Antioksidan Ekstrak Daun Garcinia lateriflora Blume Var. Javanica Boerl. Dengan Metode DPPH dan Identifikasi Senyawa Kimia Dari Fraksi yang Aktif (skripsi). Universitas Indonesia: Depok.

Silalahi, J. 2006. Makanan Fungsional. Kanisius : Yogyakarta

Sudjadi. 2010. Kimia Analisis Farmasi. Pustaka Pelajar: Yogyakarta.

Taddini, B., Juliano, C., Piu, L. 2000. Resveratiol Inhibition of Lipid Peroxidation. Free Radical Res. 33: 105-114.

Utami, Prapti. 2008. Buku Pintar Tanaman Obat. Agromedia: 
Jakarta.

Weerakkody, W. A. P., Jayakody, J. A. L. P. 2012. Bioactive Properties of Fruit Juice Pomegranate (Punica granatum L.) Grown In Dry Regions of Sri Lanka. Tropical Agricultural Research. 23(4). 370-375
Widyastuti,Niken .2010. Pengukuran Aktivitas Antioksidan dengan METODE CUPRAC, DPPH, DAN FRAP serta korelasinya dengan fenol dan flavanoid pada enam tanaman (skripsi).Institut Pertanian Bogor : Bogor 